\title{
LABOR RELATIONS: RACIALLY DISCRIMINATORY SENIORITY SYSTEM UNJUSTIFIED BY BUSINESS NECESSITY HELD TO VIOLATE TITLE VII OF THE CIVIL RIGHTS ACT OF 1964
}

Tn Local 189, Papermakers \& Paperworkers v. United States, ${ }^{1}$ the Court of Appeals for the Fifth Circuit held that a seniority system which carries forward the effects of former discriminatory practices violates Title V1I of the Civil Rights Act of 1964. Prior to 1964 Crown Zellerbach Corporation, the employer involved in the case, maintained two racially segregated lines of progression in which eyen the lowliest "white" jobs were more desirable than "Negro" jobs and in which job seniority was the basis of promotion. ${ }^{2}$ In 1966 the progression lines were merged on the basis of existing pay rates with the general result that "Negro" lines were tacked to the bottom of "white" lines. ${ }^{3}$ Job seniority based on existing pay rates continued to lock Negroes into "Negro" jobs since seniority in "white" jobs regardless of qualifications was a prerequisite in awarding all but the lowest level "white" jobs. In 1968 Crown Zellerbach adopted a promotion system combining job seniority and mill seniority despite a strike threat by the white union. After obtaining an injunction against the white union's strike and before implementation of the 1968 system, ${ }^{5}$ the government filed suit under Title VII against Crown and the whitc union, asking that job seniority not be a basis of promotion. The district court ordered implementation of a promotion system based upon mill seniority "in all circumstances in which one or more competing employees is a Negro hired prior to January $16,1966 .{ }^{\prime 6}$ The Court of Appeals affirmed.?

\footnotetext{
1_ F.2d _ (5th Cir. 1969). Although the United Paperworkers and the employer, Crown Zellerbach Corporation, are also appellants, the primary party in interest is Crown Zellerbach.

2 See id. at

${ }^{3}$ Id. at $\ldots$.

"Id. at __. "Mill seniority" is the total length of time worked at the mill on all jobs.

5 United States v. Local 189, Papermakers \& Paperworkers, 282 F. Supp. 39, 41. (E.D. La. 1968).

- Id. at 41. For an explanation of the district court's later order, see Local 189, Papermakers \& Paperworkers v. United States, F.2d (5th Cir, 1969).
} 
An analysis of the legislative history of Title V11 is useful in determining whether seniority rights are immune from the provisions of Title VII. Section 703(a)(2) makes it unlawful for an employer to adversely affect an employee's status by classification on the basis of race. ${ }^{8}$ While section 703(h) allows an employer to utilize a seniority system which is not based on racial discrimination, ${ }^{9}$ section $706(\mathrm{~g})$ requires the court to find that the discrimination was intentionally engaged in before it can enjoin the discrimination and issue a corrective order." Because the Civil Rights Act of 1964 was never referred to a Senate Committee, its legislative history is the source of some confusion concerning the immunity of seniority rights under Title VII. Senator Clark's statements that "[s]eniority rights are in no way affected by the bill" and that the "[b]ill is not retroactive"" provide support for the interpretation that seniority rights are immune from Title VII. Other factors suggest an opposite conclusion. Senator Clark did not deal with job seniority but responded to the fear of senior white workers being displaced by junior Negro workers with less mill seniority. ${ }^{12}$ Further, reading Clark's comments to prohibit the use of evidence of past discrimination in determining if a present seniority system is discriminatory would make it difficult to determine if a system is bona fide and would render Title V11 ineffective..$^{13}$ The "in any way" language of section $703(a)(2)^{14}$ is

${ }^{8}$ Civil Rights Act of $1964 \S 703$ (a)(2), 42 U.S.C. $\S 2000 \mathrm{e}-2$ (a)(2) (1964). "It shall be an unlawful employment practice for an employer-. . . (2) to limit, segregate or classify his employees in any way which would deprive or tend to deprive any individual of employment opportunities or otherwise adversely affect his status as an employee, because of such individual's race, color . . . ." Id.

' Civil Rights Act of $1964 \S 703(\mathrm{~h}), 42$ U.S.C. $\S 2000 \mathrm{e}-2(\mathrm{~h})$ (1964). “[1]t shall not be an unlawful employment praetice for an employer to apply different standards . . . pursuant to a bona fide seniority . . . system ... provided such differences are not the result of an intention to discriminate because of race, color . ..." Id.

${ }^{10}$ Civil Rights Act of $1964 \S 706(\mathrm{~g}), 42$ U.S.C. $\S 2000 \mathrm{e}-5(\mathrm{~g})(1964)$.

" 110 Cong. REc. 7217 (1964) (remarks of Senator Clark).

12 See Quarles v. Philip Morris, Inc., 279 F. Supp. 505, 516 (E.D. Va. 1968); M. SoverN, Legal Restraints ON Racial Discrimination IN EMPLOYMENT 72 (1966) [hereinafter cited as SOVERn]; Blumrosen, Seniority and Equal Employment Opportunity: A Glimmer of Hope, 23 RuTGERs L. Rev. 269, 287 (1969); Gould, Seniority and the Black Worker: Reflections on Quarles and Its Implications, 47 TEx. L. REv. 1039, 1046 (1969).

${ }^{13}$ Gould, Employment Security, Seniority and Race: The Role of Title VII of the Clvll Rights Act of 1964, 13 How. L.J. 1, 22 (1967).

"Sce note 8 supra. 
very broad and suggests that Congress intended to reach all present discrimination including that incorporated into seniority systems. $^{15}$ This suggestion is not narrowed by Section $703(\mathrm{~h})$ which is simply an assurance that bona fide seniority systems not based on race are lawful. ${ }^{16}$ Further, the union's duty to represent all of its members "without hostile discrimination against them" as set forth in Steele v. Louisville \& N.R.R. ${ }^{17}$ and extended to cover all workers $^{18}$ represented by any union ${ }^{19}$ prohibits differences in seniority based on race.20 That seniority rights are not immune under the Steele doctrine would suggest that Congress did not intend them to be so under Title V11.21 Although the "intentional" requirement of section $706(\mathrm{~g})$ could be interpreted as making seniority immune from the provisions of the Act, the record shows that Senator Dirksen inserted the word "willfully," later amended to "intentionally," to distinguish an intentional act from an accidental act. ${ }^{22}$ Thus, the legislative history of the Civil Rights Act of 1964 suggests that seniority systems were not intended to be immune and that whether a specific system violates Title V1I must be judicially determined.

Although the district courts uniformly have determined that a business necessity test should be used in seniority cases under Title VII and have generally adopted a "rightful place" approach, ${ }^{23}$ significant confusion has been created as to whether Title VII requires a specific intent to discriminate and whether a seniority system which maintains differences based on prior lawful discrimination violates Title V11. Because courts have not provided definite

\footnotetext{
${ }^{15}$ Cooper \& Sobol, Seniority and Testing Under Fair Employ'ment Laws: A General Approach to Objective Criteria of Hiring and Promotion, 82 HARv. L. REv. 1598, 1611-14 (1969).

${ }^{10}$ See Quarles v. Philip Morris, Inc., 279 F. Supp. 505, 517 (E.D. Va. 1968); Blumrosen, supra note 12, at 291; Cooper \& Sobol, supra note 15, at 1612-14; Vass, Title VII: Legislative History, 7 B.C. IND. \& CoM. L. Riv. 431,449 (1966).

1323 U.S. 192, 203 (1944); see Blumrosen, supra note 12, at 273-76.

ix IVallace Corp. v. NLRB, 323 U.S. 248 (1948).

10 Brotherhood of R.R. Trainmen v. Howard, 343 U.S. 768 (1952).

${ }^{20}$ Central of Ga. Ry. v. Jones, 229 F.2d 648 (5th Cir.), cert. denied, 352 U.S. 846 (1956).

2t Jenkins, Study of Federal Effort to End Job Bias: A History, a Status Report, and a Prognosis, 14 How. L.J. 259, 310 (1968).

22110 Cong. Rec. 8194 (1964) (remarks of Senator Dirksen); see Local 189, Papermakers \& Paperworkers v. United States, F.2d note 12, at 282-83; Cooper \& Sobol, supra note 15, at 1674-75.

2 See note 32 infra and accompanying text.
} 
guidelines defining the "business necessity" which will justify a discriminatory seniority system, a case by case analysis is desirable. In Quarles v. Philip Morris, Inc. ${ }^{24}$ where segregated lines of work were abandoned and "white" and "Negro" jobs did not require different abilities, the court ordered that mill seniority be the basis of promotion upon a finding that the impairment of efficiency, expense of retraining, and disturbance of junior employees' promotion expectations did not justify limiting transfers to "white" jobs or conditioning promotion to higher "white" jobs on job seniority. ${ }^{25}$ However, when differences in the skill and training required for a "Negro" job and a "white" job have been significant, business necessity has been found to justify job promotion systems which carry forward the effects of prior discrimination. ${ }^{26}$ Thus, in United States v. Hayes International Corp. ${ }^{27}$ where the difference was between maintenance and airplane repairing, a 24 week residency requirement was upheld for Negroes transferring into "white" jobs. ${ }^{28}$ Similarly, in Griggs v. Duke Power Co., ${ }^{29}$ where the difference was between laborer and other higher departments, business necessity was found to justify a high school education requirement for transfer from the "Negro" laborer department. ${ }^{30}$ In contrast, no business necessity was found when a union's referral system was based on a nepotic membership requirement which had no relation to one's ability to do the work. ${ }^{31}$ In another area of judicial consistency in applying Title VII to seniority provisions, most courts have adopted a "rightful place" theory which allows qualified Negroes to bid on job vacancies on the basis of mill seniority. ${ }^{32}$ Because this approach limits the disruptive effects on

279 F. Supp. 505 (E.D. Va. 1968)

${ }^{25} I d$. at $520-21$.

${ }^{26}$ See Whitfield v. Steelworkers Local 2708, 263 F.2d 546 (5th Cir.), cert. denied, 360 U.S. 902 (1959) (decided under the Steele doctrine). For criticism of Whitfield see Blumrosen, supra note 12, at 294.

27295 F. Supp. 803 (N.C. Ala. 1968).

A Id. at 808-09.

292 F. Supp. 243 (M.D.N.C. 1968).

${ }^{30} \mathrm{Id}$. at 251.

3t United States v. Sheet Mëtal Workers Local 36, F.2d (8th Cir. 1969); Local

53, Heat \& Frost Insulators \& Asbestos Workers v. Vogler, 407 F.2d 1047 (5th Cir. 1969).

32 E.g., Quarles v. Philip Morris, Inc., 279 F.Supp. 505, 510, 516 (E.D. Va. 1968); $c f$. Note, Title VII. Seniority Discrimination, and the Incumbent Negro, 80 HARv. L. Rgv. 1260, 1268 (1967). See also Blumrosen, supra note 12, at 303-04. 
white workers without sacrificing the rights of the Negro workers and maintains the employer's efficiency, it has been called a "deliberate speed" approach. ${ }^{33}$ Two other methods are the "status quo" approach which would allow seniority systems to be immune and the "freedom now" approach which would allow Negroes to replace white workers with less seniority. ${ }^{34}$ Although most cases have not discussed the intent necessary to violate Title VII, one case, in dictum, seems to require a specific intent, ${ }^{35}$ while an analogy to Radio Officers' Union v. NLRB, ${ }^{36}$ which held that the National Labor Relations Board had the power to infer intention from the factual setting, ${ }^{37}$ would lead to an opposite result. ${ }^{38}$ Commentators have urged that no specific intent requirement be imposed because of the nature of discrimination ${ }^{39}$ and that the intent can be inferred from pre-1965 discrimination if the consequences were foreseeable at the time of the discrimination. ${ }^{40}$ With the only case ${ }^{41}$ finding that present discrimination must be based on prior unlawful discrimination having been overruled ${ }^{42}$ the possibility of applying the unlawfulness requirement from other civil rights areas, which the court in Local 189 feared, would seem to be quite small. This possibility would seem to be eliminated by Gaston County v. United States ${ }^{43}$ which held invahid a literacy test which carried forward the effects of the lawful, pre-Brown, ${ }^{44}$ inferior education received by Negroes in segregated schools. ${ }^{45}$ Even if the unlawfulness requirement

30 Id. at. 1274.

${ }^{3}$ Id. at 1268-69.

${ }^{35}$ Dobbins v. Local 212, 1BEW, 292 F. Supp. 413, 443 (S.D. Ohio 1968).

ss 347 U.S. 17 (1954).

sI Id. at 52.

28 Gould, Seniority and the Black Worker: Reflections on Quarles and Its Implications, 47 Tex. L. Rev. 1039, 1052-53 (1969). Cf. NLRB v. Local 267, IBEW, 357 F.2d 51, 55 (3d Cir. 1966).

${ }^{39}$ Berg, Equal Employment Opportunity Under the Civil Rights Act of 1964,31 BROOKLYN L. KEv. 62, 71 (1964). See Blumrosen, supra note 12, at 281; Cooper \& Sobol, supra note 15, at 1675 .

to See Jenkins, supra note 21 , at 311 .

"United States v. Sheet Metal Workcrs Local 36, 280 F. Supp. 719 (E.D. Mo. 1968).

12 United States v. Sheet Metal Workers Local 36, __ F.2d __ (8th Cir. 1969).

395 U.S. 285 (1969).

$"$ Brown v. Board of Educ., 347 U.S. 483 (1954).

${ }^{15}$ Spitz, Tailoring the Techniques to Eliminate and Prevemt Employment Discrimination, 14 Buffalo L. Rev. 79, 82 (1964). 
were imposed, the Steele doctrine, ${ }^{46}$ which has been extended to cover both union and management, ${ }^{47}$ would appear to make prior racial discrimination illegal. With vagueness as to what constitutes "business necessity" and confusion as to the requirements of employer intent and prior unlawfulness, there is a lack of consistency in adjudicating seniority cases under Title VII.

The Fifth Circuit in Local 189 adopted a three-step approach which involves finding discrimination, determining business necessity, and issuing a triangularly adjusted decree, premised on an interpretation of Title VII that seniority systems are not immune from section 703(h). First, to dctermine if a violation of Title VII exists, the court held that under Crown Zellerbach's seniority system Negroes ". . . will lose promotions which, but for their race, they would surely have won" and concluded that the effects of past discrimination were being carried forward. ${ }^{48}$ ln finding present discrimination, the court interpreted the requirements of prior unlawfulness and employer intent. Adopting the Gaston County' rationale, ${ }^{49}$ the court did not require that the prior discrimination be unlawful, but only that prior discrimination affect the present job patterns. In finding that inteniion may be inferred from actions before the effective date of Title Vll, the court required only that one meant to do what was done, rather than requiring that present discrimination result from a specific intention to discriminate. 51 Second, the court held that Crown Zellerbach's discrimination was unjustified by business necessity which it defined as ". . . an overriding legitimate, non-racial business purpose." ${ }^{5} 1$ The court found that job seniority was not essential to plant efficiency or safety, and that the problems of labor unrest and training could be minimized by a well-fashioned order..$^{52}$ Finally, the court adopted the district court's order based on the "rightful place" theory which adjusts the triangu-

\footnotetext{
${ }^{16}$ See notes 17-20 supra and accompanying text.

"i Independent Metal Workers Local 1, 147 N.L.R.B. 1573 (1964); Miranda Fuel Co., 140 N.L.R.B. 181 (1962), enforcememt denied, 326 F.2d 172 (2d Cir. 1963); see Anderson, ('ivil Rights and Fair Eimplo!ment, 22 Bus. Law. 513, 514 (1967).

l:or a related extension of the Labor Management Relations Act of 1947, see United Packinghouse v. NLRB, _ F.2d _ (D.C. Cir. 1969).

ix F.2d at

${ }^{19}$ See note 43 supra and accompanying text.

so

51 Id. at

${ }^{52}$ Id. at F.2d at
} 
lar interests of minority group employees, white employees, and management. ${ }^{53}$ The court rejected a "freedom now" 54 approach because such an approach would displace incumbent whites, aggravate labor unrest, and violate the intent of Title V11.55 The court also rejected the "status quo" approach as freezing a generation of black workers, and it provided that all qualified Negroes can bid on all vacancies in jobs they would have had but for discrimination. ${ }^{56}$ The Court defined "qualified" as requiring Negroes to first bid for vacancies in the lowest level "white" jobs, to stay at such a job for a residency period, and to then bid on the basis of mill seniority for a vacancy on the next job level. ${ }^{57}$ By adopting the district court's order, the Fifth Circuit required that mill seniority with the above conditions be the basis of promotion. In justifying the order it adopted, the Fifth Circuit stated that the order protects management by allowing it to retain its option to deny promotions to employees who lack the qualifications to do the job properly, ${ }^{58}$ that it protects the white employees by providing that they will not be displaced from their jobs, and that it protects the Negro employees by allowing them to bid on job vacancies on the basis of mill seniority with only those residency requirements justified by the training needs of the job ${ }^{59}$

Local 189 is significant for the outline it provides for future decisions. The scope of the Act's prohibitions is interpreted to include present discrimination which results from prior racial discrimination that has been incorporated into a seniority system which has no business necessity. This interpretation is in accord with the legislative history which indicates that seniority rights are not immune under Title V1l and with Section 703(h) which defines a "bona fide" seniority system as one not based on race..$^{60}$ By not

\footnotetext{
See United States v. Hayes Int'l Corp., 295 F. Supp. 803, 808 (N.D. Ala. 1968); Gould, Seniority and the Black Worker: Reflections on Quarles and Its Implications, 47 TEX. L. REV. 1039, 1067-68 (1969).

s See note 34 supra and accompanying text.

is F. F. See Gould, Seniority and the Black Worker: Reflections on Quarles and Its Implications, 47 TEX. L. Rev. 1039, 1068 (1969).

so

s7 Id. at $\longrightarrow$.

ss Id. at

${ }^{3}$ Id. at

${ }^{c}$ See notes 8-22 supra and accompanying text.
} 
requiring a specific intent, by allowing inquiry into prior discrimination, and by not requiring that prior discrimination be unlawful, the court's holding allows all present discrimination to be subject to prohibition and is in accordance with the general language of section 703(a)(2). ${ }^{61}$ By adopting the "rightful place" theory, the court demonstrates that not all present effects of prior discrimination violate Title VII and properly adopts a "deliberate speed" approach ${ }^{62}$ which encourages voluntary compliance and protects the rights of both Negro and white workers. Discovery of "an overriding legitimate, non-racial business purpose" to ascertain business necessity requires a case by case determination which focuses on the interrelation of the "Negro" and "white" jobs in the areas of skills, abilities, and training. ${ }^{63}$ Once the present discrimination is found to be unlawful, it is desirable that the court consider all the interests involved and issue a triangularly adjusted decree. For instance, as the ability and training gap between two jobs narrows, maintenance of plant efficiency could require shorter residency requirements and the business necessity justification for job seniority would lessen. To make its order effective, the court should try to limit the disruptive effect of its holding so as to assure compliance and still protect the Negroes' rights through such devices as bump-back provisions, which would enable a Negro transferee to return to his former job without a Ioss in seniority, and mill seniority. ${ }^{64}$ Further, although the Fifth Circuit makes no ruling on the validity of company aptitude and skill tests having the same effect as a discriminatory seniority system, it would be desirable for future courts to apply the court's three-step reasoning when evaluating the validity of such tests.

By requiring a comprehensive three-step approach the court is likely to increase the iudicial burden in the area of seniority where the courts are not "particularly adept" ${ }^{\prime 65}$ and where adjudication of

\footnotetext{
${ }^{61}$ See note 8 supra.

${ }^{62}$ See note 33 supra and accompanying text.

${ }^{63}$ See notes 24-31 supra and accompanying text for other factors to consider in determining business necessitỳ: Quarles (efficiency, nondisturbance of junior employees' promotion expectations); Hayes (lay-offs, recalls, safety, economical performance of government contracts); Griggs (upgrading of the labor force, job function); Vogler (trade relation).

${ }^{84}$ See Blumrosen, supra note 12, at 313.

is Gould, Emplovment Securty. Seniority and Race: The Role of Title VII of the Civil Rights Act of 1964, 13 How. L.J. 1, 30 (1967).
} 
cases, as compared to the procedures of the National Labor Relations Board, are more time consuming, more costly, and more demanding procedurally. ${ }^{66}$ Three possible methods to ease this burden are to give enforcement powers to the Equal Employment Opportunity Commission, which was created under Title VII and which at least one commentator believes will become a "repository of expertise" in the area, ${ }^{67}$ to have the courts appoint labor arbitrators as masters under Rule 53 of the Federal Rules of Civil Procedure, ${ }^{68}$ or to rely more on the National Labor Relations Board, which seems to have extended Steele to cover management discrimination in seniority. ${ }^{69}$ Whichever method is chosen, the three-step approach of finding discrimination, determining business necessity, and using a triangularly adjusted decree should provide a sound guide in deciding future seniority discrimination cases.

\footnotetext{
"SOVERN, supra note 12, at 163; see Herring, The "Fair Representation" Doctrine: An Effective Weapon Against Union Racial Discrimination, 24 MD. L. REV. 113, 146-47, 16263 (1964); Rosen, The Law and Racial Discrimination in Employment, 53 CALIF. L. REv. 729, 744, 795-96 (1965).

${ }^{67}$ Gould, Employment Security, Seniority and Race: The Role of Title VII of the Civil Rights Act of 1964, 13 How. L.J. I, 31 (1967). See H.R. 6229, 91 st Cong., Ist Sess. (1969); H.R. 6228, 9lst Cong., 1st Sess. (1969); Note, Allocating Jurisdiction Over Racial Issues Between the EEOC and NLRB: A Proposal, 54 CoRnell L. Rev. 943 (1969).

'Gould, supra note 13 , at 31 .

${ }^{6}$ See notes 47 and 67 supra. Because the NLRB has only recently asserted its full jurisdiction in the freld of employment discrimination, the Board has not yet been widely utilized by litigants in this area. Miranda Fuel Co., 140 N.L.R.B. 181 (1962), enforcement denied on other grounds, 326 F.2d 172 (2d Cir. 1963), was the first NLR B decision to hold that a violation of the duty of fair representation was an unfair labor practice under the TaftHartley Act and that acquiescing management could commit this violation. Independent Metal Workers Local I, 147 N.L.R.B. 1573 (1964) extended Miranda to the field of racial discrimination but was overshadowed by the Civil Rights Act of 1964 . United Packinghouse v. NLRB, F.2d (D.C. Cir. 1969) held that management's independent discrimination violated the Taft-Hartley Act.
} 